\title{
Modeling Soft Institutional Change and the Improvement of Freshwater Governance in the Coastal Zone
}

\author{
$\underline{\text { Rémi Mongruel }}^{1}$, Jean Prou $^{2}$, Johanna Ballé-Béganton ${ }^{3}$, Michel Lample ${ }^{3}$, Alice Vanhoutte-Brunier ${ }^{1}$, Harold Réthoret ${ }^{4}$, \\ José Antonio Pérez Agúndez ${ }^{1}$, Françoise Vernier ${ }^{5}$, Paul Bordenave ${ }^{5}$, and Cédric Bacher ${ }^{6}$
}

\begin{abstract}
The contribution of soft institutional change to improve freshwater governance in the coastal zone will be examined. Freshwater management seeks to reduce losses due to overexploitation of the common-pool resources provided by river catchments and their associated ecosystems. Due to the complexity of the governance system, improving the performance of one coastal social-ecological system means searching for the appropriate "soft" institutional change. In the Pertuis Charentais region, increasing scarcity of freshwater in summer threatens the health of the coastal ecosystem and the sustainability of human activities, which depend on the use of natural resources. The allocation of freshwater among competing uses or concerns is a core issue for integrated coastal zone management. To address this issue, we have constructed an analytical framework that combines the ecosystem services approach with the institutional analysis of common-pool resources, and have developed an integrated simulation tool based on the system dynamic modeling approach. Freshwater scarcity generates three kinds of user conflict: (1) conflict between two extractive uses of freshwater (irrigation and drinking water), (2) conflicts between extractive uses (provisioning services) and other services (support, regulatory, and cultural) provided by freshwater, and (3) competition within a given activity sector (agriculture or shellfish farming). Participation by local managers led to the identification of realistic soft institutional changes that might mitigate conflicts and improve the governance system. These possible institutional changes were then integrated as fixed exogenous parameters in the simulation model. The simulated scenarios suggest that innovative collective arrangements involving farmers could be an alternative to other more restrictive top-down measures. This participatory experiment also illustrates the potential of social-ecological modeling for exploring acceptable new institutional arrangements.
\end{abstract}

Key Words: common-pool resources; ecosystem services; freshwater management; governance; institutional arrangements

\section{INTRODUCTION}

Integrated Water Resource Management (IWRM) takes place within the broader framework of environmental policies that target sustainable development, thus forming part of regional multi-objective policies such as Integrated Coastal Zone Management. IWRM seeks to facilitate the coordination of water sharing and to minimize water use conflicts, given multiple objectives, and legislative mandates (Davis 2007). IWRM is first of all a matter of "good governance" (Lundqvist 2004:414), which includes building social agreements on rules and property rights, and an administrative and enforcement structure (Rogers and Hall 2003). River catchments and their multiple uses are typical examples of social-ecological systems whose sustainability assessment requires integrated ecological, economic, and institutional approaches that take account of institutional change (Ostrom 1995, Holling et al. 2002). An empirical research agenda to improve water governance in the coastal zone should thus pay careful attention to existing user conflicts and institutions. The SPICOSA (Science and Policy Integration for Coastal Systems Assessment) project has developed a System Approach Framework (SAF) in order to address the multiple ecological and social issues raised by sustainability in the coastal zone (Hopkins et al. 2011). Some of the results obtained in the Pertuis Charentais area, one of the 18 SPICOSA study sites, will be presented. The focus is on the analytical framework and the integrated simulation model that have been built to explore institutional change for improving freshwater governance in the coastal zone.

\section{Pertuis Charentais area}

The Pertuis Charentais area is located on the French Atlantic coast (Figure 1). This site is characterized by the fragility and instability of the continuum between the freshwater from the Charente catchment, a flat hydrological basin with a pluvial regime (Giret 2002), and the coastal waters, which are subject to varying salinity gradients (Struski 2005). Most of the inhabitants live in the coastal fringe, and the inland rural areas are sparsely populated. The river catchment also includes forests and wetlands. Much of the human activity in the area requires freshwater: household consumption, agriculture, oyster cultivation, tourism, and recreation. Average annual potential freshwater consumption is 125 million $\mathrm{m}^{3}$ and faces a regular deficit of 30 million $\mathrm{m}^{3}$. Households make up 37 percent of consumption, industries 10 percent, and agriculture the remaining 53 percent. Irrigated crops are grown by 2100 farmers with a total turnover of 63 million euros (EPTB Charente 2004). The oyster farming industry relies on river

\footnotetext{
${ }^{1}$ Ifremer, UMR Amure, Marine Economics Department, ${ }^{2}$ Ifremer, head of La Tremblade Station, ${ }^{3}$ University of Brest, UMR Amure, ${ }^{4}$ EPTB Charente, ${ }^{5}$ Cemagref, ADER Research Unit, ${ }^{6}$ Ifremer, Dynamics of Coastal Environment Department
} 
nutrients for oyster growth and freshwater for spat production. Its 800 businesses provide over 5500 jobs (half part-time), and each year sell up to 50,000 tons of oysters worth 175 million euros (DPMA 2010). Its impact on local ecosystems and on the regional economy makes freshwater management a major concern for local authorities.

Fig. 1. The Charente watershed: hydrological units and adjacent coastal zone (authors' own elaboration, after Google Earth and EPTB Charente)

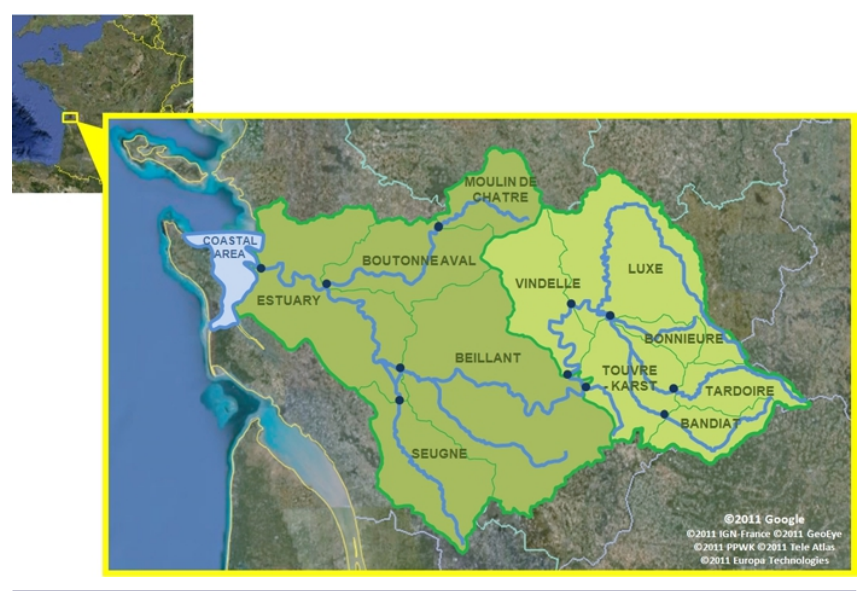

The local governance system implements regulations and management measures to maintain freshwater quality and sustainable levels of extractive use, in accordance with the protection of natural habitats and other issues affecting the population's welfare. Nevertheless, the Charente watersheds frequently experience an acute summer freshwater deficit due to low rainfall and excessive irrigation. Persisting inefficiencies in freshwater management may adversely impact both terrestrial and coastal ecosystems, and trigger latent user conflicts.

\section{Historical background}

During the last forty years, agricultural policy and repeated droughts have significantly modified land use throughout the Charente watershed; irrigated areas have increased from 3800 hectares in 1970 to 81,530 in 2000,85 percent being used for maize cultivation (Granjou and Garin 2006). The increased frequency of low-flow periods since 1976 can only be explained by water extraction for irrigation, and not by climate change (Giret 2002). Water management through authorized water volumes, gradually established since the 1990s, has reduced the frequency and intensity of crisis situations during climatically normal years. However, drought years still generate crises comparable to those of the 1990s, except in the watershed areas that can be recharged by dams with sufficient water reserves (Granjou and Garin 2006).
Since 1985, coastal and terrestrial users have been involved in management measures concerning freshwater uses. Participatory approaches have been developed by the public body in charge of freshwater management (EPTB Charente 2004), in order to organize scientific knowledge and user interactions for a better integration of terrestrial and marine concerns. However, self-interested perceptions of the sustainability problem, even if oversimplified, may still drive important water management decisions. Oyster farmers, who feared insufficient spat collection in the summer of 2006, obtained a freshwater release from the Breuil-Magné reserve, but its insignificant impact created some controversy. Many maize growers still use technical solutions initiated in the 1990s; they chiefly address the problem of freshwater deficit by adding more "substitution dams", rather than by better irrigation practices. Thus, improved scientific knowledge should also support the search for incentives that would align individual interests with the needs of the water system, and illustrate the possible outcomes of institutional change.

\section{User conflicts and institutional change}

A better understanding of natural resource management institutions calls for abandoning the unrealistic assumption that only one use of a resource is wanted, and instead considering the multiple uses of common-pool resources (Edwards and Steins 1998). The ecosystem services approach fits with this recommendation because it emphasizes the diversity of beneficiaries and highlights the conflicts produced by the numerous functions of freshwater in a coastal zone. Institutions play a key role both in the expression of people's preferences with respect to the status of ecosystem services, and in setting the processes that may directly affect these services (Pritchard et al. 2000). But while analysis of institutions has inspired much literature on common-pool resources, it has rarely been applied to ecosystem services management.

A framework for analyzing the governance of complex common-pool resources in the coastal zone will be presented, which combines the ecosystem services approach applied to the representation of competing freshwater uses with the institutional approach applied to the socio-political dimension of conflict resolution. Recent work in the field of water resource allocation and management seeks to incorporate existing institutions in system dynamic modeling approaches (Jakeman and Letcher 2003, Letcher et al. 2007). Therefore, an effort will be made here to incorporate existing governance mechanisms in a system dynamic model, enabling exploration of scenarios based on institutional changes in rules for access and user practices. Given the complex social issues inherent in water management, a significant step toward improved governance could be accomplished through soft institutional change based on local collective organization, rather than more 
drastic change based on top-down decisions. Through the participation of local managers in the project and the analysis of emerging innovative practices implemented by some user groups, realistic institutional change could be identified, in the form of more planned and collaborative behavior in the irrigated agriculture sector, the effects of which are simulated and discussed.

\section{METHODS}

\section{Defining the policy issue}

Application of the SAF began with a focus group of local administrators involved in the Charente catchment management, which included: the Southwest France (AdourGaronne basin) Regional Water Agency (AEAG), the Territorial Public Agency for the Management of the Charente (EPTB Charente), the Rivers Division of the Council of the Charente-Maritime Department (CG17), the state local spatial planning administration (DDTM-E), the state local agriculture and forestry administration (DDTM-AF), and the state local maritime affairs administration (DDTM-AM) responsible for shellfish farming policy. This stakeholder group focused on the quantitative management of the freshwater in the Charente catchment, a policy issue addressed in the regional plan for water management (SDAGE), which includes a Water Shortage Management Plan (PGE) for the Charente.

The water management scheme of the SDAGE and the PGE led to agreement on general objectives and methods. First, freshwater management priorities were established, with the highest priority being the good ecological status of coastal ecosystems, the next priority, the availability of household drinking water and the third priority, other private uses (agriculture, shellfish farming). Second, Reachable Discharge Thresholds (RDT), which are supposed to guarantee the first two uses, were defined at different control points in the river catchment. Third, the management plan's operational objective is to ensure that the system can reach the RDTs during the summer in at least eight years out of ten. Current political debate focuses on the modification of the authorized water volumes for each use and on the improvement of the limitation rules that apply to consumption during water shortages. The stakeholder group's main expectations concerned the options available for achieving the already fixed objectives of this management system.

\section{Analytical framework: complex common-pool resources,} ecosystem services, and management institutions

Freshwater is typically a complex common-pool resource, used for different purposes by multiple users under various property regimes (Edwards and Steins 1998). Such a resource may generate a range of user conflicts, both across user groups and among users in the same group. These user conflicts basically arise from two characteristics of these systems (Ostrom 1990, Ostrom 2003): imperfect excludability (it is difficult to control access to the resource because the design and implementation of clear property rights are complicated and costly, and require perpetual negotiation), and the subtractive character of certain uses (any portion of the resource appropriated by one user is no longer available to others). In the absence of coordination among users, individualistic behaviors may lead to the "tragedy of the commons" (Hardin 1968). However, in many cases users of a common-pool resource tend to engage in collective action to overcome the risk of resource overexploitation (Ostrom 1990). The question then is how to assess the effectiveness of different forms of user organization for achieving the sustainability of the social-ecological system.

The ecosystem services approach favors a better understanding of user conflicts, especially when preserving ecosystem functions is a multi-issue social concern. Ecosystem services are usually divided into four categories related to regulation, production, cultural, and support functions (de Groot et al. 2002, Millennium Ecosystem Assessment 2003). The ecosystem services associated with the availability of freshwater in the Charente catchment are depicted in Figure 2. Each category encompasses several functions, at least one of which satisfies a human need or concern considered significant in local policy debates. Four main conflicts are generated by the competing uses of the freshwater services in the catchment, the last two being classic cases of common-pool resource rivalries: (1) conflict between the two extractive uses of freshwater (irrigation and drinking water), (2) conflict between extractive uses (provisioning services) and other services (support, regulatory, and cultural) provided by freshwater, (3) rivalry among arable farmers, who are direct users of freshwater, and (4) rivalry among shellfish farmers, who are indirect users of nutrients supplied by the river to the coastal waters.

Farmers who irrigate are involved in three of the conflicts. The beneficiaries of support, regulatory, and cultural services may have shared interests and thus could form a coalition in order to reduce the access rights of the provisioning services user (conflict 2). But since shellfish farmers, recreational fishers, and indeed all of the inhabitants need drinking water, a need considered as non-negotiable, they are bound to advocate for reducing water consumption by irrigation (conflict 1). Thus, the debate over institutional change for improving freshwater governance focuses on how to redefine access rights for irrigation and improve its efficiency.

\section{Governance scheme for the Charente catchment}

The governance system of one river catchment generally functions with common objectives and tools, defined by national laws and regional plans for sectoral water management, integrated watershed management, and natural resource management. It encompasses local rules and collective agreements that deal with specific issues such as 
Fig. 2. Freshwater ecosystem services and user conflicts in the Charente catchment
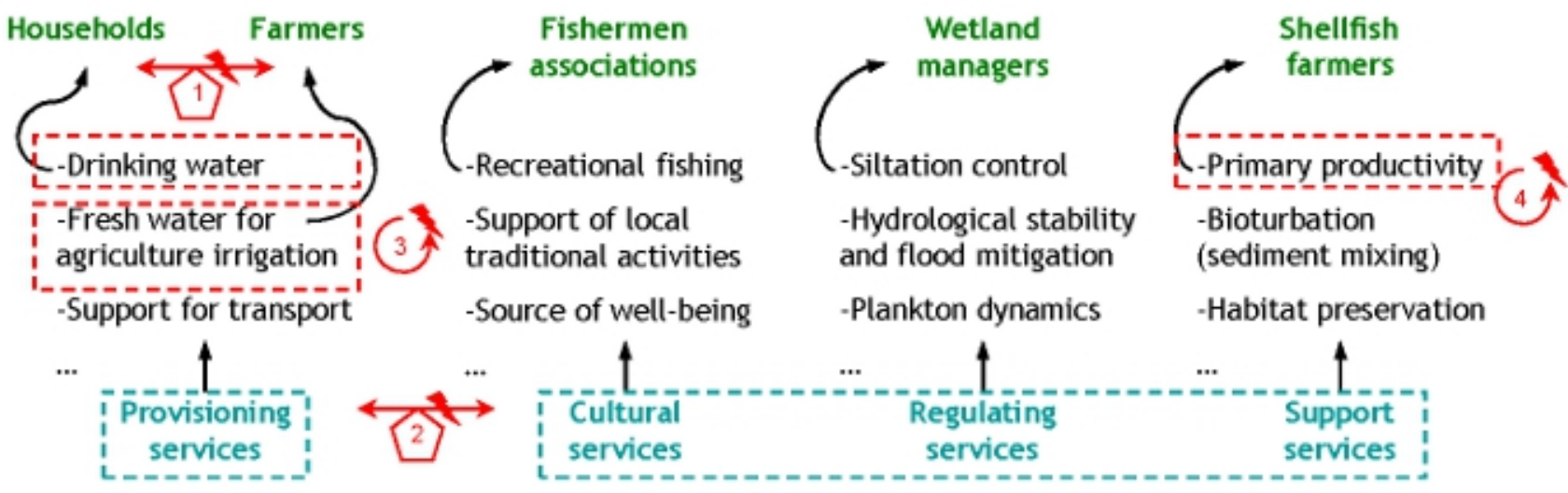

-Plankton dynamics

-Habitat preservation
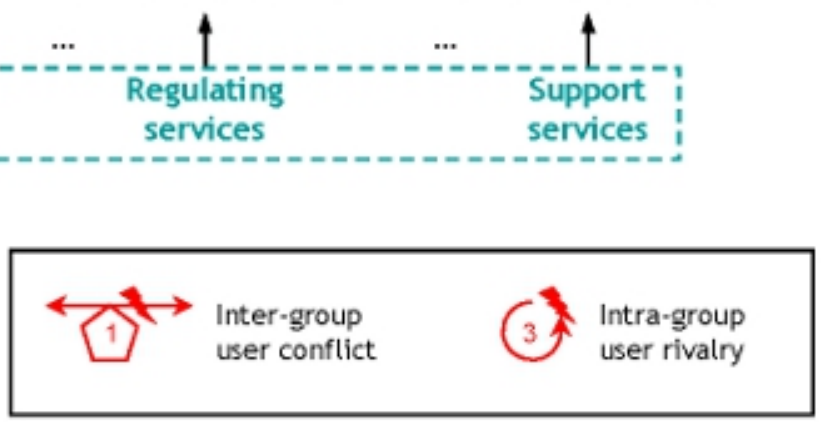

resource allocation (Davis 2007). In order to identify emerging institutional arrangements in the Charente catchment, an analysis of the freshwater governance scheme was carried out, following the hierarchy of rules defined by Kiser and Ostrom (1982): constitutional rules, collective rules, and operational rules. The multiple objective governance scheme for freshwater in the Charente catchment connects to three broad domains: water policy, agricultural policy, and shellfish farming policy (Table 1). In each domain, the policy is based on European or national laws, reflected in local collective rules, which in turn are subject to operational agreements between users and administrative bodies or among users.

The institutional arrangements that constitute local governance are designed by the letters A through F. Each arrangement should contribute to mitigating user conflict. Local rules (in particular A and C) address the mitigation of inter-group user conflicts resulting from freshwater scarcity. Operational agreements (in particular D and F) mainly address the mitigation of rivalries within one category of users of common-pool resources. However, from a system approach, mitigating intragroup rivalries could contribute to mitigating inter-group conflicts, by increasing the welfare of one user group without affecting the benefits of other groups.

In the case of irrigation systems, "disincentives of the "stateof-nature' game between head-end and tail-end farmers" (Ostrom and Gardner 1993:109) may prevent cooperation between participants. Indeed, current irrigation management
Table 1. Institutional framework for the management of freshwater and its uses

\begin{tabular}{llll}
\hline \hline & Water policy & $\begin{array}{l}\text { Agricultural } \\
\text { policy }\end{array}$ & $\begin{array}{l}\text { Shellfish } \\
\text { farming policy }\end{array}$ \\
\hline $\begin{array}{l}\text { Constitutional } \\
\text { law }\end{array}$ & $\begin{array}{l}\text { EU Water } \\
\text { framework } \\
\text { directive }\end{array}$ & $\begin{array}{l}\text { EU Common } \\
\text { agricultural } \\
\text { policy }\end{array}$ & $\begin{array}{l}\text { National Decree } \\
\text { on marine } \\
\text { cultures }\end{array}$ \\
$\begin{array}{l}\text { Local } \\
\text { collective } \\
\text { rules }\end{array}$ & $\begin{array}{l}\text { A: Hierarchy of } \\
\text { water uses } \\
\text { and crisis } \\
\text { restrictions }\end{array}$ & $\begin{array}{l}\text { Colume } \\
\text { authorized for }\end{array}$ & $\begin{array}{l}\text { E: Structural } \\
\text { scheme (leasing } \\
\text { grounds } \\
\text { allocation) }\end{array}$ \\
$\begin{array}{l}\text { Operational } \\
\text { agreements }\end{array}$ & $\begin{array}{l}\text { B: Schedule of } \\
\text { water releases }\end{array}$ & $\begin{array}{l}\text { D: Irrigation } \\
\text { schedules and } \\
\text { practices }\end{array}$ & $\begin{array}{l}\text { F: Oyster bank } \\
\text { management }\end{array}$ \\
& from dams & anagent & \\
\hline
\end{tabular}

schemes are rather different on the upstream and downstream sides of the Charente catchment. Upstream farmers face pressure from downstream users. They have thus already enforced planned, and in some cases, collaborative strategies, while downstream farmers still implement myopic, individualized ones (Labbé et al. 2000). More efficient institutional arrangements for using common-pool resources may be found through a change of governance scale (Steins and Edwards 1999). Assuming that the upstream area's 
Fig. 3. The Pertuis Charentais integrated simulation model: the user interface

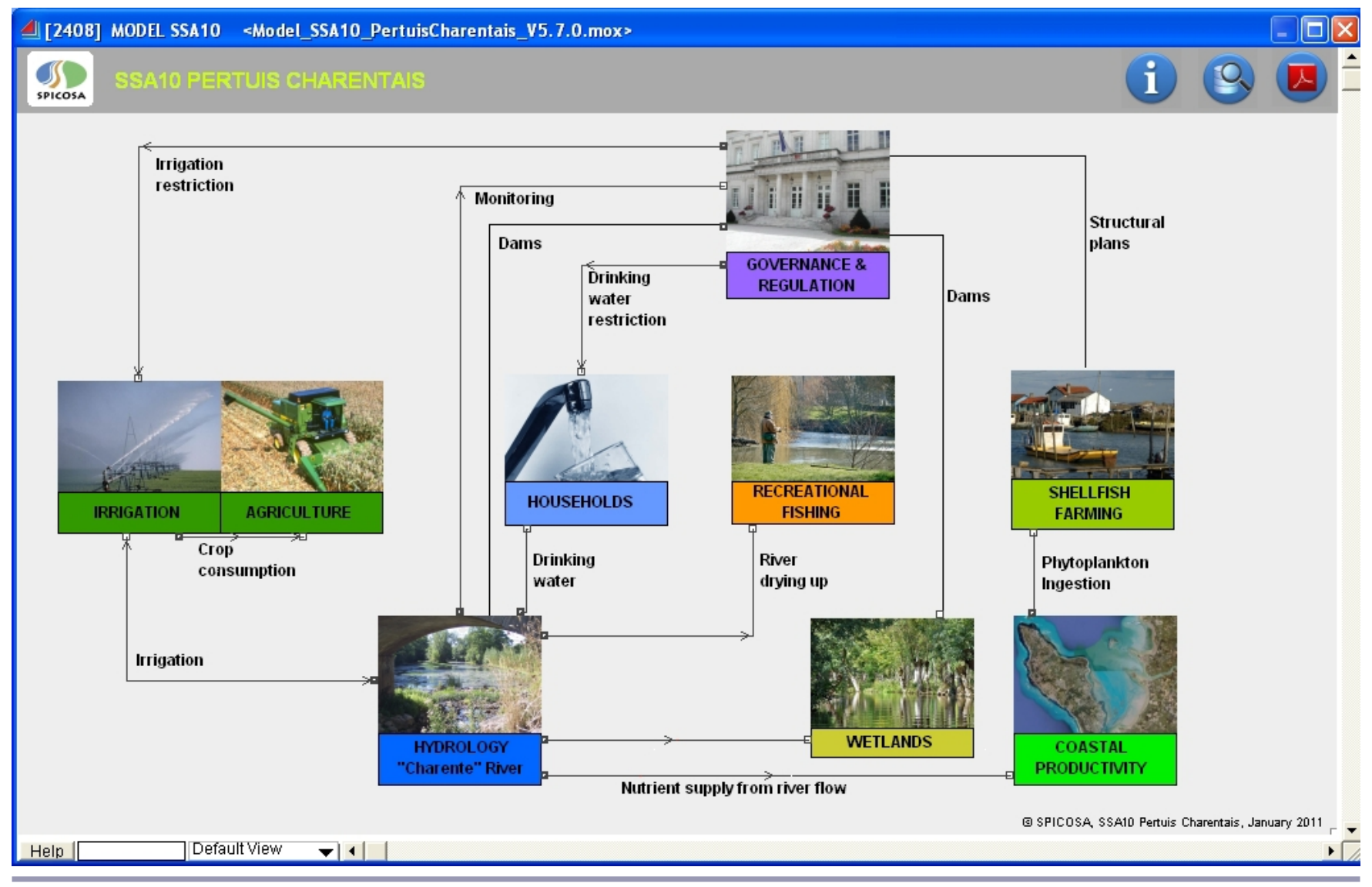

operational agreements are more efficient, the simulations will explore the gradual harmonization of the irrigation schemes at the river catchment scale. The governance scenarios thus address soft institutional change, in which improved operational agreements, based on local collective organization, are taken into consideration, rather than more drastic change through top-down decisions.

\section{The integrated social-ecological model}

An integrated simulation model based on the system approach has been developed in ExtendSim ${ }^{\mathrm{TM}}$ software. Construction of the integrated model went through three stages: (1) participatory investigation to ensure the best possible cognitive representation of the system, (2) mathematical formulation of the model's components to achieve an appropriate level of complexity, (3) development of visualization and documentation outputs for exploratory, learning, and communication purposes. The first stage was based on the Actor-Resource-Dynamics-Interactions (ARDI) methodology (Etienne et al. 2011), resulting in a model with three broad categories of components: "resources," "uses," and "governance devices." The model is organized in tiers
(Figure 3); the bottom tier represents the resource systems, including the Charente hydrology, wetlands, and coastal water productivity; the middle tier are the resource uses, including agriculture, household drinking water consumption, recreational fishing, and shellfish farming; and the top tier includes governance and regulation, including water use restrictions.

Figure 4 shows the main variables, relationships, and boundaries of the quantitative model defined for the simulation of soft institutional change. The formulation of the Charente river dynamics rewrites the equations of the hydrological model EAUCEA - CycleauPE (Filali et al. 2007) in ExtendSim $^{\mathrm{TM}}$. CycleauPE is used by Water Agency managers to monitor the daily flow levels of the Charente and restrict irrigation during droughts. The hydrological sub-model simulates daily changes in river flow for eleven hydrological sub-basins, taking into account specific features such as soil types and the geographical scale of the water regulations (Figure 1). The agriculture module is connected to the hydrological sub-model and simulates crop water consumption under various irrigation strategies. These strategies depend on the institutional arrangements chosen in 
Fig. 4. System view of freshwater allocation from the Charente: current boundaries of the simulation model and scope of the scenarios

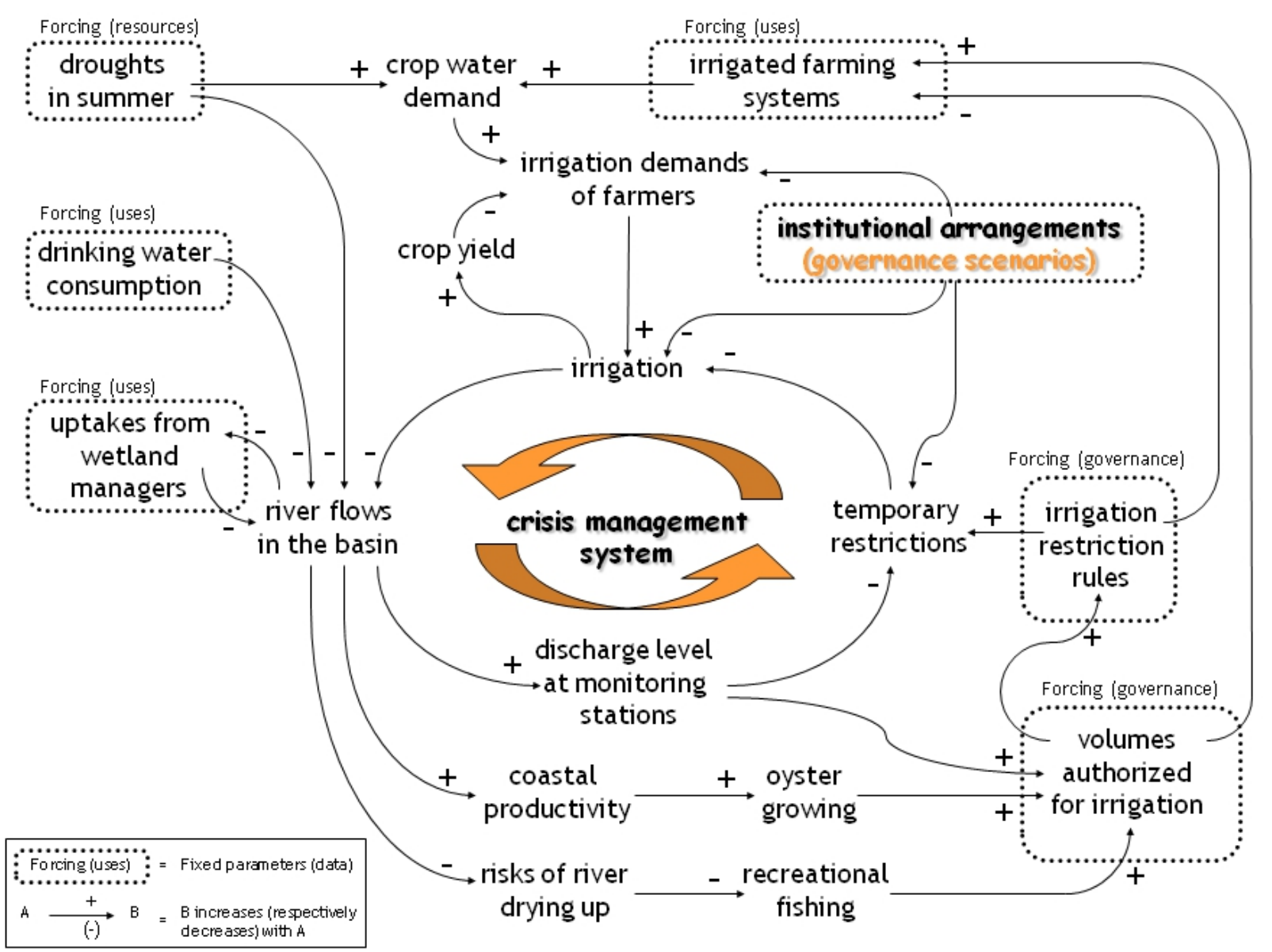

the governance module, which also simulates restriction rules triggered by critical discharge levels at monitoring stations.

To account for the influence of governance on agriculture, the model includes several institutional arrangements: the collective rules that define crisis restrictions (A in Table 1), volumes authorized for irrigation (C), and operational agreements regarding irrigation practices and strategies (D). Farmer strategies in six of the upstream sub-basins are based on a planned schedule of irrigation needs that distributes annual use-rights over segmented periods of the irrigation season (periodic strategy). Some upstream farmers have adopted collaborative irrigation strategies for severe drought situations by taking turns to pump water in some locations (collaborative strategy). Downstream farmers have access to their whole annual use-right at any time (annual strategy). The restrictions imposed by water shortages apply to this annual use-right; farmers are likely to adopt "myopic" irrigation strategies because they have no incentive to anticipate future reductions of their permitted volumes, which are far higher than their actual needs.

The variables and equations relating to institutional arrangements associated with agriculture are as follows:

- $C I D$ is the crop irrigation demand, estimated by the model using potential evapotranspiration and the factor $K c$ which links the crop water needs to its growth stage

- FID is the farmer irrigation demand, depending on local agricultural practices (it has been observed that farmers underestimate the crop demand by 25 percent) and limited by the maximum technical capacity of equipment (MTC) 
- ICC is the real irrigation consumption of crops, depending on farmer practices and irrigation authorization

- $A V$ is the annual volume of provisional authorized takings allocated to one sub-basin

- $A V^{p}$ is the provisional volume authorized per period, for a periodic irrigation strategy

- $R A V(t)$ is the real volume of takings authorized at each time step, determined by past water consumption within the current period and the possible application of crisis limitations.

At each daily time step within a given time period $p$ (year or week depending on the irrigation strategy), the irrigation consumption of crops is given by:

$$
I C C(t)=\min [F I D(t), R A V(t)]
$$

where

$$
F I D(t)=\min [0,75 \cdot C I D(t), M T C]
$$

and

$$
R A V(t)=A V^{p}(1-\alpha)-\sum_{t=1}^{t-1} I C C(t)
$$

with

$$
R A V(t) \geq 0
$$

Thus, the real volume of takings authorized depends on a parameter $\alpha$ whose value ranges from 0 to 1 and that defines the level of temporary irrigation limitations at each time step. The limitation parameters are fixed for each sub-basin by an annual bylaw, and depend on successive "alert" thresholds, the last being the "cut-off threshold" (when the value of the limitation parameter is 1 ). The number of management thresholds varies from 2 to 4 , by sub-basin and season. The model applies the limitation parameters automatically, after reading the monitoring data provided by the hydrological module. The annual irrigation strategy parallels the periodic formula, using a unique period $p$ for the entire year. The collaborative irrigation scheme assumes that farmers agree to pump water at different times when the alert threshold has been reached. Thus, in addition to $A V$ and $R A V$, taking turns pumping leads to a constraint on FID: the demand of each farmer is equal to zero in one day out of two, meaning that only half of the fields are irrigated each day within the subbasin when this operational agreement applies.
The coastal waters module estimates the effect of freshwater availability on phytoplankton production, taking into account seawater turbidity (forced by in situ data) and light conditions. Though recent studies suggest that phosphate may play a key role in phytoplankton dynamics (Struski 2005), this model, like previous ones for this area (Raillard and Ménesguen 1994, Bacher et al. 1998), uses nitrate as the nutrient limiting primary production. The oysters feed on this unique trophic resource. Their growth is determined by a Dynamic Energy Budget model validated for Crassostrea gigas by Pouvreau et al. (2006) and Bacher and Gangnery (2006). The growth cycle lasts two to four years. During the year, farmers regularly grade the oysters in order to sell the marketable ones. Each spring, they replenish the cohorts of oysters (spat, half-grown, and adult oysters) in accordance with the size classes needed to reach the production target of 43,000 tons (Pérez Agúndez et al. 2010). At that time, the model provides an annual accounting of harvested (final production) and half-grown oysters (intermediate production).

\section{RESULTS}

The exploratory scenarios are based on feasible improvements in the governance of water use-rights for irrigated agriculture. Current dominant management rules constitute the two baseline scenarios. The upstream irrigation strategies are assumed to be more efficient in preventing crisis events that lead to severe restrictions on irrigation. The exploratory scenarios thus consider the gradual deployment of the assumed best irrigation strategies from the upstream area toward the entire Charente catchment (Table 2).

Table 2. Combinations of irrigation strategies in the baseline and exploratory scenarios

\begin{tabular}{lcc}
\hline \hline & \multicolumn{2}{c}{ Irrigation strategy } \\
\cline { 2 - 3 } & Upstream area & Downstream area \\
\hline Baseline scenario 1: PA & Planned & Annual \\
Baseline scenario 2: CA & Collaborative & Annual \\
Exploratory scenario 1: PP & Planned & Planned \\
Exploratory scenario 2: CP & Collaborative & Planned \\
Exploratory scenario 3: CC & Collaborative & Collaborative \\
\hline
\end{tabular}

\section{Limitation of crisis events}

Reachable discharge thresholds (RDTs) are always assumed to be achieved during winter; the period of low water flow begins on April 1 and may last until the end of December. Figure 5 shows the effects of institutional change on the RDTs; for each sub-basin of the Charente catchment the simulations estimate the number of days when river flow is below the alert threshold (restriction of irrigation) or below the cut-off threshold (no irrigation). Ten hydrological units are monitored over nine months, giving 2750 daily observations per simulation. As the effectiveness of institutional change may 
also depend on climatic conditions, simulations have been run for a reference year (mean climatic conditions) and for a dry year. The current move toward collaborative strategies in the upstream area (scenario CA) is efficient for a dry year only. Implementing "planned irrigation strategies" in the downstream area (scenario PP) would reduce crisis events during a normal year but would have no effect during a dry year. In contrast, expanding "collaborative irrigation strategies" to the whole catchment (scenario CC) would be much more beneficial under all climatic conditions; critical crisis events would decrease by 22 percent during a dry year and 52 percent during a normal year.

Fig. 5. Number of days with irrigation restrictions depending on institutional change
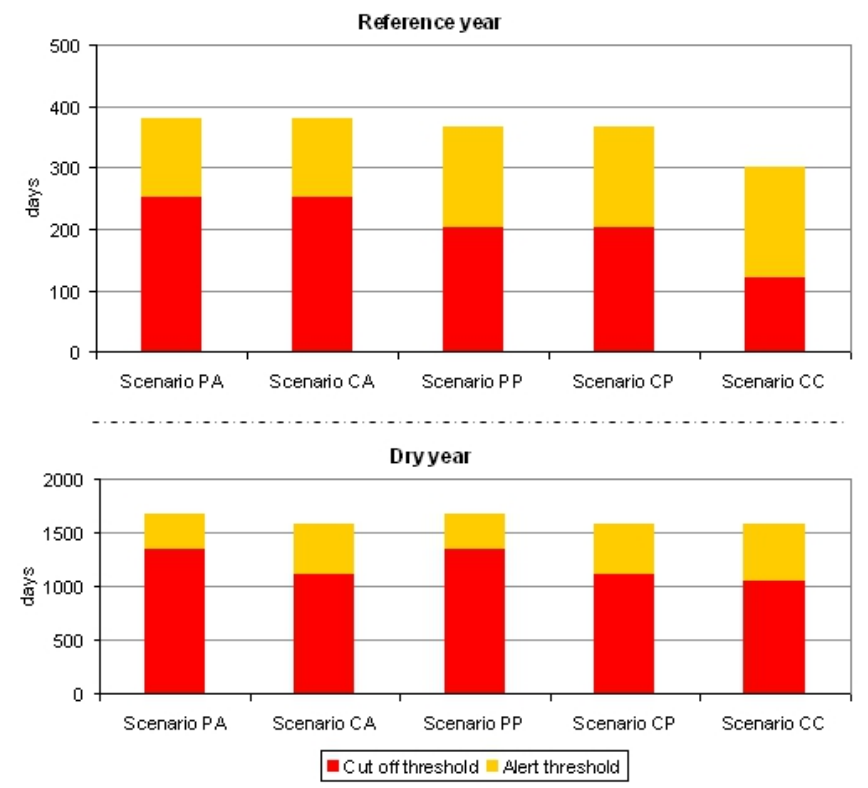

Whatever the irrigation strategy, the irrigation demand is much higher than the irrigation consumption of crops, in particular during dry years when less than one third of the demand is satisfied (Figure 6). Enforcing planned and collaborative strategies would reduce consumption by irrigated crops by negligible amounts during a normal year. During a dry year, the institutional change that would maximize environmental benefits (scenario CC) would not only result in a decrease in irrigation consumption by no more than 8 percent, but also ensure a much better distribution of consumption over the irrigation period than other management scenarios. Figure 7 illustrates the river's contribution to coastal productivity for the two extreme governance scenarios; under given climatic conditions, institutional change has a negligible effect on the total input of nutrients to the coastal zone. In contrast, the nutrient loads might be cut by more than half during severe drought.

\section{Economic impacts of governance change}

Economic assessment of the scenarios is based on variations in productivity of agriculture and shellfish farming. Crop yields depend on total evapotranspiration, which characterizes yield potential, and water stress, a risk factor at the flowering stage. The model calculates the impact of freshwater availability on the crop yield, expressed in tons of dry matter per hectare (TDM/ha); irrigation exerts a major influence on crop production, which would fall from 10 to $7 \mathrm{TDM} / \mathrm{ha}$ without irrigation in comparison with completely unrestricted irrigation. These results indicate that any attempt to preserve coastal ecosystems through irrigation practices that consume less water would also probably mean productivity losses for arable farming. Future social compromises will then have to consider how much productivity loss is acceptable in return for the expected environmental benefits. However, the simulations suggest that, when achieved through soft institutional change, significant positive effects on the environment (expressed in terms of crisis event reduction) would generate fairly reasonable decreases in irrigation consumption (Table 3).

Fig. 6. Crop irrigation demand and consumption depending on institutional change
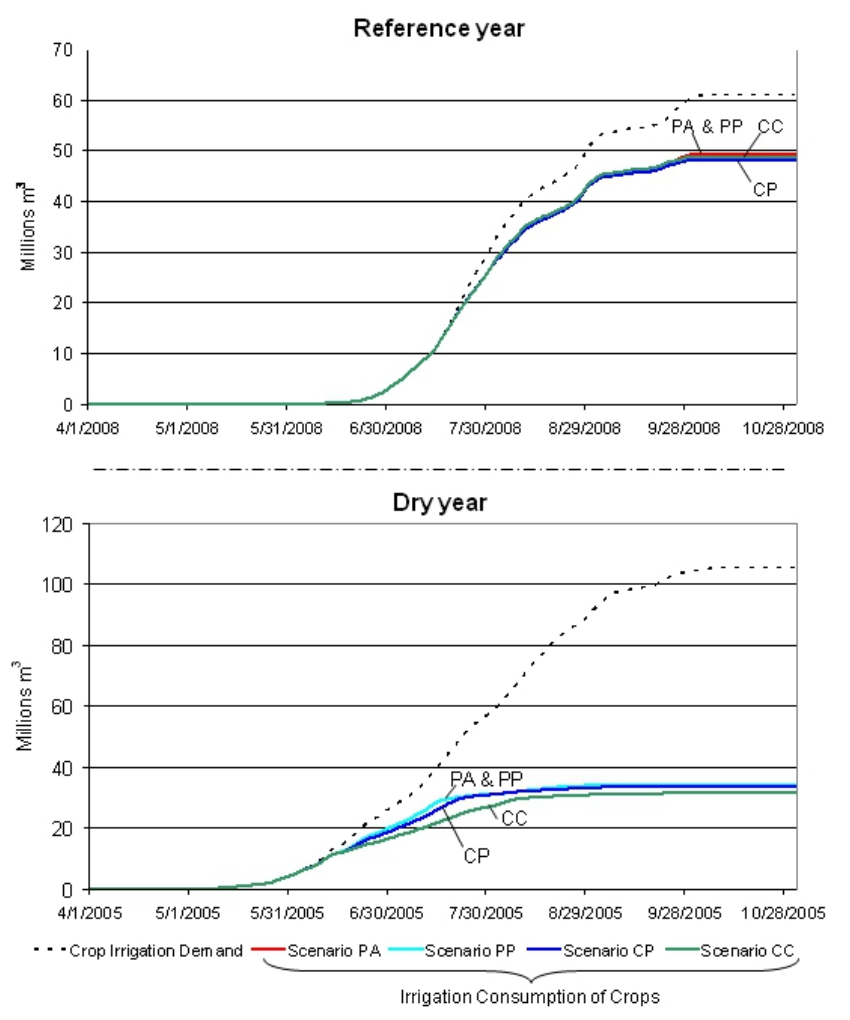

Note: Scenarios PA, CA (not represented) and PP show veny minor differences (see also Table 3). 
Table 3. Crisis events and irrigation consumption depending on institutional change

\begin{tabular}{|c|c|c|c|c|c|}
\hline Crisis events & PA (No of days) & $\mathrm{CA} \% \mathrm{PA}$ & $\mathrm{PP} \% \mathrm{PA}$ & $\mathrm{CP} \% \mathrm{PA}$ & $\mathrm{CC} \% \mathrm{PA}$ \\
\hline Reference year: alerts & 380 & $0 \%$ & $-3 \%$ & $-3 \%$ & $-20 \%$ \\
\hline Reference year: cuts & 252 & $0 \%$ & $-19 \%$ & $-19 \%$ & $-52 \%$ \\
\hline Dry year: alerts & 1661 & $-5 \%$ & $0 \%$ & $-5 \%$ & $-6 \%$ \\
\hline Dry year: cuts & 1332 & $-17 \%$ & $0 \%$ & $-17 \%$ & $-22 \%$ \\
\hline Irrigation consumption & PA (millions $\mathrm{m}^{3}$ ) & $\mathrm{CA} \% \mathrm{PA}$ & $\mathrm{PP} \% \mathrm{PA}$ & $\mathrm{CP} \% \mathrm{PA}$ & $\mathrm{CC} \% \mathrm{PA}$ \\
\hline Reference year & 49.5 & $0 \%$ & $-2 \%$ & $-2 \%$ & $-1 \%$ \\
\hline Dry year & 34.5 & $-2 \%$ & $0 \%$ & $-2 \%$ & $-8 \%$ \\
\hline
\end{tabular}

Coastal productivity is much more sensitive to interannual changes in precipitation than to the institutional arrangements regarding freshwater use (Figure 8). Intermediate production (half-grown oysters) is much more sensitive to the availability of primary production than the harvested production, and may decrease by $24 \%$ during a dry year. As improved irrigation strategies have no positive effect on their production during normal years, this may explain why oyster farmers prefer to concentrate their demands on the possibility of obtaining freshwater releases during severe droughts. However, the shellfish farm model does not yet include summer spawning and larvae fixation on collectors. Since huge natural mortality regularly affects the oyster stock, a better understanding of the influence of physicochemical factors on spat production is needed. The effects of the timing of the introduction of freshwater inputs into coastal waters should also be further examined.

Fig. 7. Effect of changes in irrigation strategy on nutrient loads in coastal waters

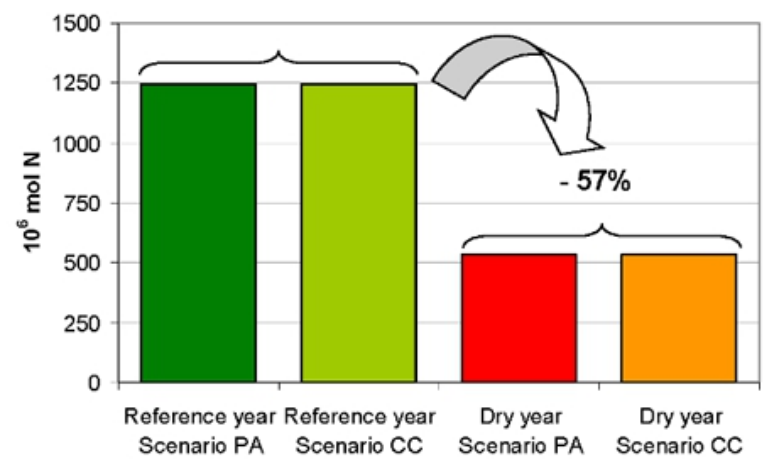

\section{DISCUSSION}

\section{Better understanding of freshwater governance}

Protecting the ecosystems that depend on the Charente has been made the primary objective of water governance, an objective held to be achieved when crisis situations due to an unbalanced water budget are avoided eight years out of ten. This "zero crisis" criterion is much more likely to be met during normal years than during dry years. The results of the simulation model suggest two directions for improved freshwater governance: implementing planned individual strategies on the downstream area is a necessary condition for

Fig. 8. Simulation of coastal primary production and oyster production

\section{Primary production}
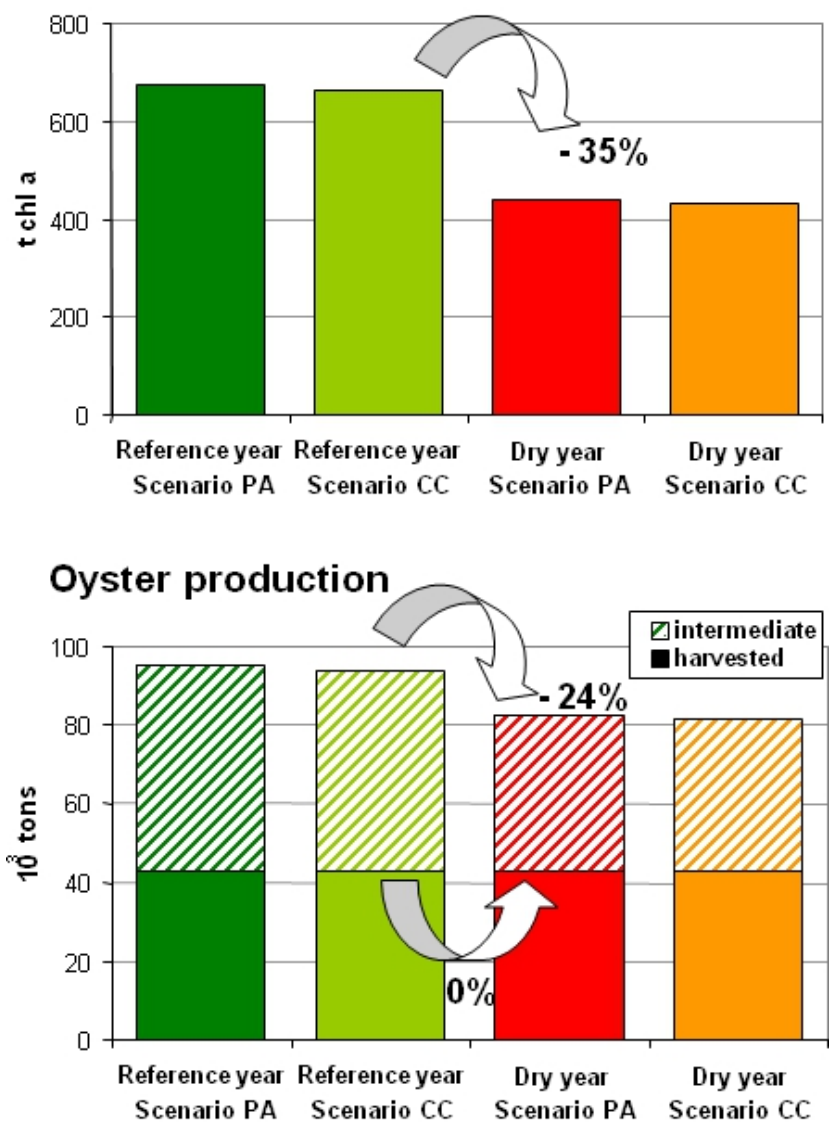
avoiding crisis events during normal years (scenario PP), and the most efficient institutional scheme for all climatic conditions would be to implement collaborative strategies in the entire river catchment (scenario CC). Thus, our results support some of the arguments of stakeholders who recommend or try out innovative institutional arrangements. They also provide further indications of the limits and conditions of validity of these new arrangements. These results are interesting for two practical reasons in particular. First, during periods of low river flow local managers recommend weekly, or even daily, monitoring of the water uptakes in order to observe the reachable discharge threshold in each hydrological unit; this decentralized and timely water management requires active participation by farmers as well as coordination of their irrigation strategies. Second, soft institutional change based on improved participation and scheduling may be more enforceable than radical institutional change based on restrictive rules. Indeed, farmers may prefer self-limitations whose efficiency relies on mutual control rather than compliance with rules imposed by an external authority.

In addition to local institutional change, development at higher levels of management will affect both stakeholder behavior and ecological issues. New reforms of the European Common Agricultural Policy remove some former irrigation subsidies. This seems to be effective, as irrigated areas have begun to diminish in the Charente catchment. However, irrigation strategies based on planned and cooperative behavior remain necessary for achieving environmental objectives, especially in view of a possible increase in summer droughts. With rising freshwater scarcity, the ability of local communities to match the pace of institutional improvement with global change dynamics will be of major importance.

Improved freshwater governance is intended to resolve user conflicts. Institutional movement toward more collaborative irrigation illustrates how reducing the intragroup rivalry within the arable farming sector may also contribute to mitigating conflicts with other users of this complex commonpool resource. Similarly, the current level of production in the shellfish farming basin is based on empirical knowledge of its carrying capacity, translated into collective rules for exploitation (the "structural scheme"), whose efficiency for reducing intragroup rivalry is not assessed here. Implicit consensus regarding their global right to produce justifies the legitimate resource needs of shellfish farmers and supports their claims for access rights to regular freshwater discharge from the Charente. Finally, this case study suggests that the efficiency of the "individual use-right" system within one user group may also determine how this user group will negotiate "global access rights" with other user groups.

\section{Unresolved science and policy debates in the Pertuis Charentais region}

The systems approach helps in studying the conflicts generated by a multiple-use common-pool resource. However, by making the interconnectedness of use more explicit, it may make some beneficiaries of indirect and uncertain use-rights insist on more objective and stable use-rights. For instance, despite the uncertainty of the outcome, shellfish farmers obtained a dam release in the summer of 2006 in order to protect the oyster spat. Yet the impact of summer river flow on oyster farming remains scientifically controversial. The primary coastal food resource is necessary to feed adult cultivated oysters and directly affects the larval growth; however, few scientific publications connect the presence of food resources to larvae survival, which also depends on temperature. While all these processes are described in the scientific literature, they are not explained sufficiently to support efficient integrated mathematical models (Héral 1991, Soletchnik et al. 1997).

Oyster farmers have by now grasped the scientific connection between freshwater volumes, nutrient loads, trophic resources, maturation, larvae survival, and spat density. But at the same time scientists and oyster farmers disagree once the connection is reduced to a direct relationship between freshwater fluxes and spat density. In practice, the success of spat collection is known around the end of the summer, while freshwater outflow is scarce during July and August. The oyster farmers' opinion may thus not be based on observed spat density but rather correlated to poor spring growth performances among adult oysters. Despite regulations and management plans for oyster density, biomass, invasive species, and abandoned leasing grounds, growth performances are lower in the Marennes-Oléron basin than in other shellfish cultivation areas. The first stages of the production cycle are now frequently carried out at other sites with better performance, such as Normandy, Brittany, the Mediterranean, Ireland, and Portugal, and spring and autumn growth is critical for ensuring that adult oysters will reach ideal market size before the high sales period (Christmas/New Year). Lastly, when spring growth has been insufficient, the summer gives oyster farmers the opportunity to demand better sharing of freshwater use, to answer the need for spat recruitment success and adult oyster autumn growth.

A similar controversy may arise relative to crop water stress. Agronomic models may suggest that irrigation is only indispensable during specific stages of growth. This could lead local authorities to vary the level of irrigation restrictions during the summer, and to consider that use-rights for irrigation are absolute at some times but precarious at others. By contrast, the farmers who employ excessive irrigation in order to secure their targeted yield may then confuse this overuse of freshwater with the real critical crop need. This confusion would impede the adoption of more adaptive useright systems based on the changing needs of crops over time. Cost-benefit estimates could be developed to highlight the potential benefits of more parsimonious irrigation; however, this in turn would require that farmers were confident about the assumptions of the production module of the simulation 
model, which ought to be consistent with their empirical knowledge.

\section{CONCLUSION}

Together with a focus group of coastal zone managers, a systemic dynamic model has been developed for the simulation of soft institutional change for improving freshwater governance in the Charente catchment. The model was primarily intended as a discussion tool for the focus group, and was therefore kept as simple as possible. While the coastal system modeled remains sensitive to the chosen formulations, the forcing data, and the assumptions, it offers a global representation of the system's functioning that matches the perceptions of each participant. The simulated scenarios have helped identify potentially effective soft institutional change, while demonstrating that innovative collective arrangements involving farmers could be an alternative to other more restrictive top-down measures for allocating water use-rights. The results show how soft institutional change within one user community can help mitigate broader user conflicts in the coastal zone.

The outputs of the simulations are expressed in terms of ecosystem services' physical availability and production yield, which is a first step toward estimates of costs, benefits, and their distribution. For collaborative institutions transaction costs should also be taken into account, since these costs may discourage the emergence of effective partnerships (Lubell et al. 2002). From a broader perspective, when the sustainability of a complex common-pool resource is at stake, some users may develop adaptive strategies by searching for alternative resources in external areas; this is already true for oyster farmers, who carry out the early stages of the growth cycle in other production basins. Such strategies may indicate decreasing robustness of the social-ecological system, since adaptive behaviors prefer solutions other than collective action against resource overexploitation (Anderies et al. 2004).

Despite the limitations of a first-time application, the SAF demonstrates significant value in gaining the interest and participation of stakeholders from varied backgrounds. Once participants felt confident that the model accounted for their own concerns, they became more interested in changes elsewhere in the system other than in the domain they already knew. In the next step of the application, this social learning process would be expected to arise for other stakeholders, especially as the perception of the ecological effects of freshwater scarcity differs substantially by user group. For instance, on the upstream side, excessive freshwater consumption is immediately noticed because rivers dry up, while on the downstream side, the river still seems to flow even if in reality it has become quasi-static. However, efforts at more efficient freshwater management should obviously be distributed equitably at both ends of the catchment.

As the choice of management institutions is not a one-shot decision in a known environment, it is always necessary to analyze how institutional rules affect the behavior of participants and the results they can achieve (Ostrom 1993, Steins and Edwards 1999). This is why the results presented here are not intended as an end point; the simulation platform should be developed and passed on to local managers to explore new rules under unforeseen environmental conditions in a more operational context. Such critical issues as the credibility of the modeling approach may then arise; indeed, empirical knowledge on the interaction between uses and the natural system, as yet neither demonstrated nor disproved by scientific models, is still dominant among the oyster farmers and arable farmers of the Pertuis Charentais region.

\section{RESPONSES TO THIS ARTICLE}

Responses to this article are invited. If accepted for publication, your response will be hyperlinked to the article. To submit a response, follow this link. To read responses already accepted, follow this link.

\section{ACKNOWLEDGMENTS}

This work was funded by the European Commission under the 6th Framework Programme, Priority 1.1.6.3 "Global Change and Ecosystems" (IP SPICOSA, project N ${ }^{\circ}$ 2007-036992). The authors wish to thank the representatives of local management bodies who participated in the project. The views expressed here are those of the authors only.

\section{LITERATURE CITED}

Anderies, J. M., M. A. Janssen, and E. Ostrom. 2004. A framework to analyze the robustness of social-ecological systems from an institutional perspective. Ecology and Society 9(1):18. [online] URL: http://www.ecologyandsociety.org/vol9/ iss $1 / \operatorname{art} 18 /$

Bacher, C., P. Duarte, J. G. Ferreira, M. Héral, and O. Raillard. 1998. Assessment and comparison of the Marennes-Oléron Bay (France) and Carlingford Lough (Ireland) carrying capacity with ecosystem models. Aquatic Ecology 31:371-394.

Bacher, C., and A. Gangnery. 2006. Use of dynamic energy budget and individual based models to simulate the dynamics of cultivated oyster populations. Journal of Sea Research 56:140-155. http://dx.doi.org/10.1016/j.seares.2006.03.004

Davis, M. D. 2007. Integrated water resource management and water sharing. Journal of Water Resources Planning and Management 133(5):427-445. http://dx.doi.org/10.1061/(ASCE) $\underline{\text { 0733-9496(2007)133:5(427) }}$

de Groot, R. S., M. Wilson, and R. Boumans. 2002. A typology for the description, classification, and valuation of ecosystem functions, goods and services. Ecological Economics 41 (3):393-408. http://dx.doi.org/10.1016/S0921-8009(02)00089-7 
DPMA. 2010. Enquête aquaculture 2008. Direction des Pêches Maritimes et de l'Aquaculture (DPMA), Ministère de l'Agriculture, de l'Alimentation et de la Pêche. Paris, France.

Edwards, V. M., and N. A. Steins. 1998. Developing an analytical framework for multiple-use commons. Journal of Theoretical Politics 10(3):347-383. http://dx.doi.org/10.1177 10951692898010003008

EPTB Charente. 2004. Plan de gestion des étiages: bassin de la Charente. Institution interdépartementale pour l'aménagement du fleuve Charente et de ses affluents (EPTB Charente). Saintes, France.

Etienne, M., D. R. Du Toit, and S. Pollard. 2011. ARDI: a coconstruction method for participatory modeling in natural resources management. Ecology and Society 16(1): 44. [online] URL: http://www.ecologyandsociety.org/vol16/iss1/ $\underline{\operatorname{art} 44 /}$

Filali, R ., B. Coupry, and J. Neveu. 2007. La gestion du cycle de l'eau a l'échelle du bassin fluvial de la Charente. Géologues 154:9-14.

Giret, A. 2002. L'hydrologie de la Charente entre nature et anthropisation (1960-1994). Science et changements planétaires. Sécheresse 13(2):105-112, Notes de recherche.

Granjou, C., and P. Garin. 2006. Organiser la proximité entre usagers de l'eau: le cas de la gestion volumétrique dans le bassin de la Charente. Développement durable et territoires, Dossier Proximité et environnement. [online] URL: http://dev eloppementdurable.revues.org/index2694.html

Hardin, G. 1968. The tragedy of the commons. Science 162: 1243-1248. http://dx.doi.org/10.1126/science.162.3859.1243

Héral, M. 1991. Approches de la capacité trophique des écosystèmes conchylicoles: synthèse bibliographique. ICES Marine Science Symposia 192:48-62. http://dx.doi.org/http:// dx.doi.org/10.1126/science.162.3859.1243

Holling, C. S., L. H. Gunderson, and D. Ludwig. 2002. In quest of a theory of adaptive changes. Pages 3-22 in L.H. Gunderson and C.S. Holling, editors. Panarchy: understanding transformations in human and natural systems. Island Press, Washington, D.C., USA.

Hopkins T. S., D. Bailly, and J. Støttrup. in press. A systems approach framework for coastal zones. Ecology and Society.

Jakeman, A. J., and R. A. Letcher. 2003. Integrated assessment and modelling: features, principles and examples for catchment management. Environmental Modelling and Software 18(6):491-501. http://dx.doi.org/10.1016/S1364-8152 (03)00024-0

Kiser, L., and E. Ostrom. 1982. The three worlds of action, a metatheoretical synthesis of institutional approaches. Pages
179-222 in E. Ostrom, editor. Strategies of political inquiry. Sage, Beverly Hills, California, USA.

Labbé, F., P. Ruelle, P. Garin, and P. Leroy. 2000. Modelling irrigation scheduling to analyse water management at farm level, during water shortages. European Journal of Agronomy 12(1):55-67. http://dx.doi.org/10.1016/S1161-0301(99)00043$\underline{X}$

Letcher, R. A., B. F. W. Croke, and A. J. Jakeman. 2007. Integrated assessment modelling for water resource allocation and management: a generalised conceptual framework. Environmental Modelling \& Software 22(5):733-742. http://d x.doi.org/10.1016/j.envsoft.2005.12.014

Lubell, M., M. Schneider, J. T. Scholz, and M. Mete. 2002. Watershed partnerships and the emergence of collective action institutions. American Journal of Political Science 46 (1):148-163. http://dx.doi.org/10.2307/3088419

Lundqvist, L. J. 2004. Integrating Swedish water resource management: a multi-level governance trilemma. Local Environment 9(5):413-424. http://dx.doi.org/10.1080/135498 3042000255324

Millennium Ecosystem Assessment (MEA). 2003. Ecosystems and human well-being - a framework for assessment. Island Press, Washington, D.C., USA.

Ostrom, E. 1990. Governing the commons: the evolution of institutions for collective action. Cambridge University Press, New York, New York, USA.

Ostrom, E. 1993. Design principles in long-enduring irrigation institutions. Water Resources Research 29(7):1907-1912. htt p://dx.doi.org/10.1029/92WR02991

Ostrom, E. 1995. Designing complexity to govern complexity. Pages 33-45 in S. Hanna and M. Munasinghe, editors. Property rights and the environment: social and ecological issues. Beijer International Institute of Ecological Economics and The World Bank, Washington, D.C., USA.

Ostrom, E. 2003. How types of goods and property rights jointly affect collective action. Journal of Theoretical Politics 15(3):239-270. http://dx.doi.org/10.1177/0951692803015003002

Ostrom, E., and R. Gardner. 1993. Coping with asymmetries in the commons: self-governing irrigation systems can work. Journal of Economic Perspectives 7(4):93-112.

Pérez Agúndez, J. A., J. Ballé-Béganton, R. Mongruel, C. Bacher, O. Le Moine, P. Soletchnik, S. Robert, and S. Guesdon. 2010. Bio-economic effects of water shortages on shellfish farming. An integrated dynamic modelling approach. In D. A. Swayne, W. Yang, A. A. Voinov, A. Rizzoli, and T. Filatova, editors. Modelling for environment's sake. Proceedings of the 2010 International Congress on 
Environmental Modelling and Software. Fifth Biennial Meeting, July 5-8 2010, Ottawa, Canada.

Pouvreau, S., Y. Bourles, S. Lefebvre, A. Gangnery, and M. Alunno-Bruscia. 2006. Application of a dynamic energy budget model to the Pacific oyster, Crassostrea gigas, reared under various environmental conditions. Journal of Sea Research 56:156-167. http://dx.doi.org/10.1016/j.seares.2006 .03 .007

Pritchard Jr., L., C. Folke, and L. Gunderson. 2000. Valuation of ecosystem services in institutional context. Ecosystems 3 (1):36-40. http://dx.doi.org/10.1007/s100210000008

Raillard, O., and A. Ménesguen. 1994. An ecosystem box model for estimating the carrying capacity of a macrotidal shellfish system. Marine Ecology Progress Series 115:117-130. http://dx.doi.org/10.3354/meps115117

Rogers, P. and J-P. Hall. 2003. Effective water governance. TEC Background Papers 7. Global Water Partnership, Stockholm, Sweden.

Soletchnik, P., D. Razet, P. Geairon, N. Faury, and P. Goulletquer. 1997. Écophysiologie de la maturation sexuelle et de la ponte de l'huître creuse (Crassostrea gigas): réponses métaboliques (respiration) et alimentaires (filtration et absorption) en fonction des différents stades de maturation. Aquatic Living Resources 10:177-185. http://dx.doi.org/10.10 51/alr:1997019

Steins, N. A. and V. M. Edwards. 1999. Collective action in common-pool resource management: the contribution of a social constructivist perspective to existing theory. Society \& Natural Resources 12(6):539-557. http://dx.doi.org/10.1080/0 $\underline{89419299279434}$

Struski, C. 2005. Modélisation des flux de matières dans la baie de Marennes-Oléron: couplage de l'hydrodynamisme, de la production primaire et de la consommation par les huîtres. Dissertation. University of La Rochelle, La Rochelle, France. 